\title{
Identification of bioactive compounds in gambier (Uncaria gambir) liquid by-product in West Sumatra, Indonesia
}

\author{
AKHIS SOLEH ISMAIL ${ }^{1}$, YOSE RIZAL ${ }^{2, \boldsymbol{v}}$, ARMENIA ${ }^{3}$, ANWAR KASIM ${ }^{4}$ \\ ${ }^{1}$ Doctor Program, Department of Animal Nutrition and Feed Science, Faculty of Animal Science, Universitas Andalas. Jl. Unand, Kampus Limau Manis, \\ Padang 25163, West Sumatra, Indonesia \\ ${ }^{2}$ Department of Animal Nutrition and Feed Science, Faculty of Animal Science, Universitas Andalas. Jl. Unand, Kampus Limau Manis, Padang 25163, \\ West Sumatra, Indonesia. Tel.: +62-751-72400, Fax.: +62-751-71464, •email: yrizal@ansci.unand.ac.id, ismail.akhissoleh@gmail.com \\ ${ }^{3}$ Department of Pharmacology, Faculty of Pharmacy, Universitas Andalas. Jl. Unand, Kampus Limau Manis, Padang 25163, West Sumatra, Indonesia \\ ${ }^{4}$ Department of Crops Technology, Faculty of Agriculture Technology, Universitas Andalas. Jl. Unand, Kampus Limau Manis, Padang 25163, West \\ Sumatra, Indonesia
}

Manuscript received: 23 November 2020. Revision accepted: 25 February 2021.

\begin{abstract}
Ismail AS, Rizal Y, Kasim A. 2021. Identification of bioactive compounds in gambier (Uncaria gambir) liquid by-product in West Sumatra, Indonesia. Biodiversitas 22: 1474-1480. Gambier liquid by-product (GLB) is a by-product of gambier production, alleged to contain similar flavonoid compounds. Currently, there is no available information on the active components of GLB. This study, therefore, aims to identify the active compounds in GLB using Fourier transform infrared spectroscopy (FTIR), and screen for active compounds using liquid chromatography coupled to quadrupled the mass spectrometry time of flight (LC-MS/MS QTOF) positive (ESI+) and negative (ESI-) ionization modes. The results of the functional-group identification spectra showed 5 peaks, and the GLB was characterized by a hydroxyl group $(\mathrm{OH})$ at $3423.22 \mathrm{~cm}^{-1}$ wavelength, indicating a phenolic compound. Meanwhile, $\mathrm{CO}_{2}$ was identified at 2360.92 and $2344.84, \mathrm{C}=\mathrm{O}$ at 1654.43 and $\mathrm{C}-\mathrm{H}$ stretching at $1400.26 \mathrm{~cm}^{-1}$ wavelength. LC-MS/MS screening in ESI+ mode identified that the GLB contained 22 active compounds, while the ESI- mode confirmed that the GLB had 14 active compounds. Based on these two ionization modes, nine compounds, quercetin 3-glucoside, gallocatechin-4beta-OI, (-)-epi-afzelechin, quercetin-3-O-(2G- $\alpha$ Lrhamnosyl)-rutinoside, kaempferol-3-O- $\beta$-rutinoside, quercetin-3-O- $\alpha$-L-rhamnoside, epigallocatechin 3-O-P-coumarate, quercetin 3O-(6"-acetyl-galactoside) 7-O-rhamnoside and quercetin 3-(4"-acetylrhamnoside) 7-rhamnoside were discovered. Therefore, GLB was discovered to contain 27 active compounds that all of these compounds are flavonoid group, and some of these substances are also present in the gambier product.
\end{abstract}

Keyword: FTIR, gambier, gambier liquid by-product, flavonoid, LC-MS/MS

\section{INTRODUCTION}

Indonesia is the world's largest exporter of gambier (gambier product), and this export value is estimated to meet about $80 \%$ of the international market's need. The largest production occurs in the province of West Sumatra, and was estimated at 2,491.39 tons in 2018 (BPS, 2020). This gambier production is mostly performed on a small scale by local farmers.

The gambier is the hot water extract of the gambier plant's (Uncaria gambir (Hunter) Roxb.) leaves and twigs. This extract is often chewed as a herb, ingested for antidiarrhea and antioxidant properties by the people (Musdja et al. 2017; Arief et al. 2020; Labanni et al. 2020), and comprises of $7.63-23.16 \%$ water, $12.24-24.16 \%$ tannins, $14.76-86.71 \%$ catechins, $1.43-25.24 \%$ ash as well as 5.58$46.28 \%$ water-insoluble compounds (Rahmawati et al. 2012; Kasim et al. 2015). A study by Sazwi et al. (2013) also reported the gambier to contain $21.77 \%$ quinic acid, $6.02 \%(+)$-catechin, $17.96 \%$ procyanidin dimer (B1), $7.06 \%$ (epi) afzelechin-(epi) catechin, $12.16 \%$ proanthocyanidin dimer, $1.61 \%$ (-)-epicatechin, $5.34 \%$ catechin isomer, $3.07 \%$ proanthocyanidin dimer, $14.79 \%$ quercetin diglycoside, $4.3 \%$ cyanidin-3-O-glucoside,
$2.02 \%$ quercetin and $0.005 \%$ kaempferol, while Kasim et al. (2019) stated gambier product contained pyrocatechol and phloroglucinol.

The extraction process starts from boiling the leaves and twigs for about 1 hour, followed by pressing, and straining. The extract obtained is then left to stand for 24 hours to become thickened. Subsequently, draining is performed to reduce the water content, followed by molding and drying, to obtain the gambier product (gambier) (Andasuryani et al. 2014), while the water collected after draining is referred to as 'gambier liquid byproduct' (GLB) or as 'kalincuang', by the local gambier farmers in West Sumatra. However, GLB has not been optimally utilized, and is even often treated as a waste.

According to Sofyan et al. (2015), this by-product is equivalent to about $4 \%$ of the total gambier product and is composed mainly of the water separated from the thick extract during draining. However, GLB is also assumed to contain several similar active compounds, as the gambier products, because it is a part of gambier extraction. Therefore, GLB is also a potential raw material for native medicinal herbs. Currently, there is no available information on the active compounds in GLB, hence, this study aims to identify these compounds, and provide a 
basis for the utilization of GLB in native medicines, as well as other applications.

\section{MATERIALS AND METHODS}

\section{Materials}

The materials used in this study include gambier liquid by-product (GLB), cotton, methanol, chloramphenicol, and biotin. The GLB was obtained from the local farmers manufacturing gambier products, in Siguntur Muda Village, Koto XI Tarusan District, Pesisir Selatan Regency, West Sumatra, Indonesia.

\section{Methods}

Gambier Liquid By-product (GLB) preparation: The GLB was filtered with cotton to separate the insoluble materials, and then stored at $-4^{\circ} \mathrm{C}$, prior to use, to protect the active components from damage. This was followed by freeze-drying (Christ Alpha 1-2 LDplu freeze dryer) at $55^{\circ} \mathrm{C}$, and vacuuming with Vacubrand RZ 2.5 to obtain a powder with a constant weight (Torres et al. 2010).

Functional group screening: This was performed by preparing a 5 to $10 \%$ mixture of GLB powder and powdered $\mathrm{KBr}$, and subjecting this mixture to Fourier transform infrared spectroscopy (FTIR) (Thermo scientific, Nicolet iS10), as described by Pavia et al. (2001), to scan the sample within the range of 4000 to $400 \mathrm{~cm}^{-1}$. Subsequently, functional groups were identified based on the absorption band at specific wavelengths.

Active compound screening: This was performed using LC-MS/MS-QTOF, as described by Qiao et al. (2013).

Standard preparation: The standard was used to confirm normality in the LC-MS/MS instrument. Therefore, biotin (Sigma Aldrich) and Chloramphenicol (Sigma Aldrich) were adopted as the positive (ESI+) and negative mode (ESI-), respectively. The following standard preparations were made: (i) Biotin 1 ppm: $25 \mu \mathrm{L}$ of 1000 $\mathrm{mg} / \mathrm{L}$ biotin standard was piped in a $25 \mathrm{~mL}$ volumetric flask $25 \mathrm{~mL}$, aquabides was added until the $25 \mathrm{~mL}$ mark was reached, and the mixture was homogenized, and then injected to the LC-MS/MS instrument. (ii) Chloramphenicol 1 ppm: $25 \mu \mathrm{L}$ of $1000 \quad \mathrm{mg} / \mathrm{L}$ chloramphenicol was piped into a $25 \mathrm{~mL}$ volumetric flask $25 \mathrm{~mL}$, aquabides were added until the $25 \mathrm{~mL}$ mark was reached, and the mixture was homogenized, and then injected into the LC-MS/MS instrument.

Sample preparation: $0.5 \mathrm{~g}$ of the GLB powder was mixed with $5 \mathrm{~mL}$ of methanol placed in a $10 \mathrm{~mL}$ volumetric flask, then subjected to ultrasonic for 30 minutes. Subsequently, methanol solvent was added until the $10 \mathrm{~mL}$ mark was reached, and the mixture was homogenized, filtered with $0.22 \mu \mathrm{m}$ mesh size GHP/PTFE membrane filter and $10 \mu \mathrm{L}$ of the filtrate was injected into UPLC with LC system: ACQUITY UPLC I-Class with FTN Sample Manager, column: ACQUITY UPLC HSS T3 $2.1 \times 100 \mathrm{~mm}, 1.8 \mu \mathrm{m}$, at a column temperature of $40^{\circ} \mathrm{C}$, auto-sampler temperature of $15^{\circ} \mathrm{C}$ and mobile phase: water $(0.1 \%$ formic acid) and acetonitrile. Meanwhile the MS condition was MS system: Xeno G2-S QTof MS, acquisition range: $100-1500 \mathrm{Da}$, scan time: $0.1 \mathrm{~s}$, acquisition mode: ESI+, ESI-; resolution mode; MS ${ }^{\mathrm{E}}$, lock mass: leucine encephalin (LE) $1 \mathrm{ppm}$ (scan for $0.3 \mathrm{~s}$, interval: $15 \mathrm{~s}$ ) capillary voltage: $3 \mathrm{KV}(\mathrm{ESI}+) / 2.5 \mathrm{KV}$ (ESI), cone voltage: $100 \mathrm{~V}$, collision energy: low CE: $6 \mathrm{eV}$; high Ce: $15-40 \mathrm{eV}$, source temp.: $120^{\circ} \mathrm{C}$, desolvation temp.: $500^{\circ} \mathrm{C}$, cone gas flow: $30 \mathrm{~L} / \mathrm{h}$, desolvation gas flow: $1000 \mathrm{~L} / \mathrm{h}$ and acquisition time: $20 \mathrm{~min}$.

Result Interpretation: The LC-MS/MS QTOF screening for active natural compounds was carried out using UNIFI software, including a mass spectrum library of active natural compounds from the waters database. Therefore, the software was able to identify the sample's active components by matching the spectrums with the library. The criteria for this identification include mass error reading of the analyte $\leq 5 \mathrm{ppm}$, isotope match MZ RMS $\leq$ 6 , analyte intensity $>300$, and one fraction with brake value $<4$, in the fragment match elucidation system.

\section{Data analysis}

All of the screening of GLB active compounds was Duplo, and then the data average was displayed in graphs and tables, descriptive analysis was carried out.

\section{RESULTS AND DISCUSSION}

\section{Screening for phenolic groups using FTIR}

Figure 1 shows the result of functional group screening for gambier liquid by-product (GLB), using Fourier transform infrared spectroscopy (FTIR). According to this figure, 5 peaks appeared in the FTIR spectrum of GLB. The first peak appears at $3423.22 \mathrm{~cm}^{-1}$, indicating the presence of a hydroxy group $(\mathrm{OH})$, and this is characteristic of phenolic compounds bound to benzene (C6) (Packialakshmi and Naziya 2014). This was in accordance with the report by Rajiv et al. (2016), stating the peak at $3332.99 \mathrm{~cm}^{-1}$, was characteristic of phenol groups $(\mathrm{O}-\mathrm{H}$ stretch, H-bond). Furthermore, the peaks at 2360.92 and $2344.84 \mathrm{~cm}^{-1}$ indicate the presence of carbonate $\left(\mathrm{CO}_{2}\right)$ compounds, while the peaks at $1654.43 \mathrm{~cm}^{-1}$ and 1400.26 $\mathrm{cm}^{-1}$ were due to $\mathrm{C}=\mathrm{O}$ and $\mathrm{C}-\mathrm{H}$ stretching, respectively (Packialakshmi and Naziya 2014; Rege and Yang 2001; Yu and Chuang 2016). From the results of screening for functional groups using FTIR, it was known that in GLB there were phenolic group compounds then screening active compounds was carried out using LC-MS/MS QTOF positive and negative ionization modes.

\section{Screening of active compounds by LC-MS/MS QTOF}

Figures 2 and 3 show the chromatogram results of active compound screening, using positive (ESI+) and negative (ESI-) ionization modes, respectively. Tables 1 and 2 show the resume of active compounds in the GLB. The data observed were detected based on chromatogram and mass spectrum obtained from LC-MS/MS QTOF. 
Table 1. The GLB flavonoid compounds identified by LC-MS/MS QTOF ESI+

\begin{tabular}{|c|c|c|c|c|c|c|}
\hline Compound & Formula & $\begin{array}{c}\text { RT } \\
(\text { min) }\end{array}$ & $\begin{array}{c}\text { Response } \\
\text { (se) }\end{array}$ & $\begin{array}{c}\text { Area } \\
\text { width (\%) }\end{array}$ & $\begin{array}{c}\text { Molecule } \\
\text { weight }(\mathrm{g} / \mathrm{mol})\end{array}$ & $\operatorname{MS}^{\mathrm{E}} \operatorname{Spectra}(\mathbf{m} / \mathbf{z})$ \\
\hline Quercetin 3-Glucoside & $\mathrm{C} 21 \mathrm{H} 20 \mathrm{O} 12$ & 3.32 & 5162 & 2.10 & 464.1217 & $951.1817,755.1809,487.0856,482.1297,313.0569$ \\
\hline $3^{\prime}, 4^{\prime}, 7$-Trihydroxy-flavone & $\mathrm{C} 15 \mathrm{H} 10 \mathrm{O} 5$ & 4.15 & 1053 & 0.43 & 270.0531 & $1174.3377,581.1626,579.1515,427.1034$ \\
\hline Gallocatechin-4beta-OI & $\mathrm{C} 15 \mathrm{H} 14 \mathrm{O} 8$ & 4.28 & 1619 & 0.66 & 322.0691 & $1109.3925,755.1904,531.2346,323.0771,139.0403$ \\
\hline 1,2,3,5-3,5-Dihydroxy-4',7-Dimethoxyflavanone & $\mathrm{C} 17 \mathrm{H} 16 \mathrm{O} 6$ & 4.32 & 1011 & 0.41 & 316.0952 & $1174.3378,867.2153,579.1516,289.0718$ \\
\hline 3-(3,4-Dihydroxycinnamoyl) Quinic Acid & $\mathrm{C} 16 \mathrm{H} 18 \mathrm{O} 9$ & 4.59 & 3210 & 1.31 & 354.0952 & $959.2193,603.1479,582.1691,581.1658,355.1032$ \\
\hline Tanariflavanone A & $\mathrm{C} 30 \mathrm{H} 36 \mathrm{O} 7$ & 4.63 & 2818 & 1.15 & 508.2262 & $889.1977,867.2142,648.2079,531.2341,355.1032,323.0771$ \\
\hline Norcimifugin & $\mathrm{C} 15 \mathrm{H} 16 \mathrm{O} 6$ & 5.92 & 26663 & 10.85 & 292.0945 & $925.1635,601.1353,579.1508,293.1025$ \\
\hline (-)-epi-Afzelechin & $\mathrm{C} 15 \mathrm{H} 14 \mathrm{O} 5$ & 5.92 & 15330 & 6.24 & 274.0844 & $925.1635,601.1353,579.1508,293.1025$ \\
\hline Quercetin-3-O-(2G- $\alpha$-Lrhamnosyl)-rutinoside & $\mathrm{C} 33 \mathrm{H} 40 \mathrm{O} 20$ & 7.11 & 8852 & 3.60 & 756.2105 & $853.2327,757.2185,643.2656,611.1609,531.2340,303.0508$ \\
\hline Kaempferol-3-O-(2G- $\alpha$-L-rhamnosyl)-rutinoside & C33H40O19 & 7.69 & 13784 & 5.61 & 740.2165 & $853.2349,741.2245,595.1670,520.3339,288.0594,287.0562$ \\
\hline $3^{\prime}, 4^{\prime}, 7-$ Trihydroxyflavanone & $\mathrm{C} 15 \mathrm{H} 12 \mathrm{O} 5$ & 7.92 & 1851 & 0.75 & 272.0685 & $1142.3076,835.2233,563.1554,409.0927,273.0765$ \\
\hline Cyanidin 3,5-diglucoside_1 & $\mathrm{C} 27 \mathrm{H} 30 \mathrm{O} 16$ & 8.02 & 22447 & 9.14 & 610.1538 & $1065.3146,644.2690,643.2658,575.2246,517.2190,303.0510$ \\
\hline Aloer & $\mathrm{C} 28 \mathrm{H} 28 \mathrm{O} 11$ & 8.28 & 6646 & 2.71 & 540.1470 & $1049.3178,903.2558,757.1990,619.1450,563.1550,339.1706$ \\
\hline erol-3-O- $\beta$-rutinoside & $\mathrm{C} 27 \mathrm{H} 30 \mathrm{O} 15$ & 8.69 & 11620 & 4.73 & 594.1585 & $933.2670,613.3409,608.3856,595.1665,563.1553,449.1088,287.0558$ \\
\hline Quercetin-3-O- $\alpha$-L-rhamnoside & $\mathrm{C} 21 \mathrm{H} 20 \mathrm{O} 11$ & 8.98 & 8148 & 3.32 & 448.1009 & $\begin{array}{l}913.3189,903.2559,711.2744,644.2685,643.2654,627.2694,449.1089 \text {, } \\
287.0559\end{array}$ \\
\hline Epigallocatechin 3-O-P-cou & ด & 9.32 & & 2.1 & 452.11 & $1197.3831,932.3331,931.3297,799.2285,454.1218,453.1183$ \\
\hline Quercetin 3-O-(6"-acetyl-galactoside) 7-O-rhamnoside & $\mathrm{C} 29 \mathrm{H} 32 \mathrm{O} 17$ & 10.35 & 13125 & 5.3 & 652.1622 & $1197.3699,684.2901,675.1514,653.1702,621.2223,329.1282,303.0501$ \\
\hline Kaempferol 2G-coumaroylrutinoside & $\mathrm{C} 36 \mathrm{H} 36 \mathrm{O} 17$ & 10.68 & 5521 & 2.25 & 740.1926 & $887.2593,741.2006,627.2690,621.2225,497.1434,353.1857,287.0553$ \\
\hline 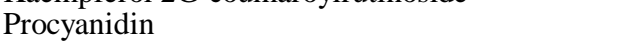 & $\mathrm{C} 30 \mathrm{H} 26 \mathrm{O} 13$ & 10.68 & 1435 & 0.58 & 594.1373 & $887.2593,741.2006,627.2690,621.2225,497.1434,353.1857,287.0553$ \\
\hline Quercetin 3-(4"-acetylrhamnoside) 7-rhamnoside & $\mathrm{C} 29 \mathrm{H} 32 \mathrm{O} 16$ & 11.14 & 7852 & 3.20 & 636.1680 & $931.3278,660.1611,628.2720,627.2686,575.2227,465.1024,339.2063$ \\
\hline Quercetin & $\mathrm{C} 15 \mathrm{H} 10 \mathrm{O} 7$ & 11.88 & 57904 & 23.57 & 302.0424 & $909.2861,622.2261,361.1544,303.0504$ \\
\hline Kaempferol & $\mathrm{C} 15 \mathrm{H} 10 \mathrm{O} 6$ & 13.82 & 24325 & 9.90 & 286.0476 & $911.3008,605.2279,330.1316,287.0556$ \\
\hline
\end{tabular}

Table 2. The flavonoid compounds that were identified in GLB using LC MS/MS QTOF ESI- mode

\begin{tabular}{|c|c|c|c|c|c|c|}
\hline Compound & Formula & $\begin{array}{l}\text { RT } \\
\text { (min) }\end{array}$ & $\begin{array}{l}\text { Response } \\
\text { (Se) }\end{array}$ & $\begin{array}{l}\text { Area } \\
\text { width (\%) }\end{array}$ & $\begin{array}{l}\text { Molecule } \\
\text { weight }(\mathrm{g} / \mathrm{mol})\end{array}$ & $\mathrm{MS}^{\mathrm{E}} \operatorname{Spectra}(\mathbf{m} / \mathbf{z})$ \\
\hline Gallocatechin-4beta-OI & C15H14O8 & 4.66 & 4719 & 2.53 & 322.0687 & $1145.3326,865.2015,611.1410,389.1081$, \\
\hline (-)-Epigallocatechin & $\mathrm{C} 15 \mathrm{H} 14 \mathrm{O} 7$ & 4.73 & 2237 & 1.20 & 306.0735 & $969.2696,779.2274,679.1883,391.1154,389.1081$ \\
\hline 7,4',3'-Triglycidyloxy-3,5-dihydroxyflavone & $\mathrm{C} 24 \mathrm{H} 22 \mathrm{O} 10$ & 6.73 & 2893 & 1.55 & 470.1214 & $1159.3108,833.2092,615.1253,579.1494,469.1127$ \\
\hline Quercetin-3-O-(2G- $\alpha$-Lrhamnosyl)-rutinoside & $\mathrm{C} 33 \mathrm{H} 40 \mathrm{O} 20$ & 7.1 & 25362 & 13.58 & 756.2124 & $1077.3091,851.2197,755.2044,635.1821,333.0603$ \\
\hline Quercetagetin 6,3'-dimethyl ether 3-(2"-apiosylgentiobioside) & $\mathrm{C} 34 \mathrm{H} 42 \mathrm{O} 22$ & 7.16 & 2819 & 1.51 & 802.2185 & $1093.3081,879.2184,867.2151,801.2099,793.1818,433.1126$ \\
\hline Quercetin 3-glucoside & $\mathrm{C} 21 \mathrm{H} 20 \mathrm{O} 12$ & 8.41 & 15996 & 8.56 & 464.0961 & $901.2428,741.2001,561.1398,463.0880,289.0708$ \\
\hline Kaempferol-3-O- $\beta$-rutinoside & $\mathrm{C} 27 \mathrm{H} 30 \mathrm{O} 15$ & 8.7 & 25298 & 13.55 & 594.1596 & $1155.3012,741.1871,651.1577,539.1516,561.1406,539.2125$ \\
\hline Quercetin-3-O- $\alpha$-Lrhamnoside & $\mathrm{C} 21 \mathrm{H} 20 \mathrm{O} 11$ & 8.98 & 14093 & 7.55 & 448.1012 & $1047.3037,879.2196,609.1486,447.8931,435.1282,315.0866$ \\
\hline Epigallocatechin 3-O-P-coumarate & $\mathrm{C} 24 \mathrm{H} 20 \mathrm{O} 9$ & 9.33 & 28792 & 15.42 & 452.1113 & $929.3178,487.0803,451.1033,341.0664$ \\
\hline 5-hydroxy-3',4'-dimethoxy-6,7-methylenedioxyisoflavone & $\mathrm{C} 18 \mathrm{H} 14 \mathrm{O} 7$ & 9.33 & 3788 & 2.03 & 342.0744 & $929.3178,487.0803,451.1033,341.0664$ \\
\hline Quercetin 3-O-(6"-acetyl-galactoside) 7-O-rhamnoside & $\mathrm{C} 29 \mathrm{H} 32 \mathrm{O} 17$ & 10.36 & 35477 & 19.00 & 652.1655 & $1047.3019,687.1349,651.1575,561.1410$ \\
\hline Quercetin 3-(4"-acetylrhamnoside) 7-rhamnoside & $\mathrm{C} 29 \mathrm{H} 32 \mathrm{O} 16$ & 11.15 & 21764 & 11.65 & 636.1697 & $937.2118,671.1395,635.1617,463.0885$ \\
\hline Kaempferol 3-(6-acetylgalactoside) & $\mathrm{C} 23 \mathrm{H} 22 \mathrm{O} 12$ & 11.49 & 2210 & 1.18 & 490.1121 & $1183.4474,929.3177,901.2421,593.1519,587.1879,489.1040$ \\
\hline (-)-epi-Afzelechin & $\mathrm{C} 15 \mathrm{H} 14 \mathrm{O} 5$ & 13.59 & 1313 & 0.70 & 274.0840 & $\begin{array}{l}\text { 1169.3637, 955.4959, } 911.3073,857.4575,671.2634,625.2567 \text {, } \\
274.0807,273.0763\end{array}$ \\
\hline
\end{tabular}


Based on the screening results of active compounds based on the positive ionization method (ESI+) (Figure 2), GLB was discovered to contain 22 active compounds, and most of these active compounds were quercetin compounds with an area of $23.57 \%$ (Table 1), appearing at 11.88 minutes, with a response of 57904 se (Figure 4). Quercetin is one of the largest flavonoid compounds belonging to the flavonols group (Materska 2008). Therefore, the presence of this compound in GLB is from the Gambier plant (Uncaria gambir (Hunter) Roxb). GLB is obtained through hot water extraction of the gambier plant (Andasuryani et al. 2014) and quercetin is water-soluble, although the solubility is small (Oliver et al. 2018), therefore the compound is highly present in GLB. A study by Sazwi et al. (2013) reported gambier to contain up to $2.02 \%$ of quercetin compounds, and $14.79 \%$ of quercetin diglycoside.

Meanwhile, in the positive ionization method (ESI+), a compound procyanidin, with an area of $0.58 \%$ appeared at 10.68 minutes with a response of 1435 se (Table 1), which procyanidin or called tannin condense is combination of two or more of catechin/epicatechin, epigallocatechin, epicatechin gallate, dimer catechin, fisetinidin, chebulic acid (Shi et al. 2020) by polymerization reaction because of heating of boiling on the process of extracting gambier. Catechin is characteristic of a gambier product active compound, and is similar to the report by Rahmawati et al. (2012); Sazwi et al. (2013), and Kasim et al. (2015) in gambier product. The catechin has been known well with many functions, such as antioxidant and anti-cholesterol (Zheng et al. 2020). Table 1 shows the active compounds detected after screening GLB using ESI+ mode LC MS/MS QTOF.

The results of chromatogram of the negative ionization mode (ESI-) active compound screening (Figure 3) and mass spectrum (Table 2) show 14 flavonoid group compounds contained in GLB. This is lesser compared to the positive ionization mode (ESI+) counterpart. This difference is due to the different types of ions used (ESI+ and ESI-), and is in accordance with the report by Zeng et al. (2018), stating the compounds identified in active compound screening using LC-MS/MS QTOF, was influenced by the ions type used.

Meanwhile, in the ESI- mode, the highest compound identified was quercetin 3-O-(6"-Acetyl-Galactoside) 7-Orhamnoside, with an area of $19.00 \%$, appearing at 10.36 minutes, with a response of 35477 se (Figure 5). The flavan-3-ol group of compounds is characteristic of the main active compounds in gambier product, also present in GLB as (-)-epigallocatechin. This appeared on the ESImode LC-MS/MS QTOF screening, with an area of $1.26 \%$, at 4.72 minutes, and with a response of 2237 se (Table 2). Table 2 shows the GLB flavonoid compounds found after the ESI- mode LC-MS/MS QTOF screening.

In addition, nine active compounds were identified using both the ESI+ and ESI- modes. These include gallocatechin-4beta-OI, quercetin-3-O-(2G- $\alpha$-Lrhamnosyl)rutinoside, quercetin 3-glucoside, kaempferol-3-O- $\beta$ rutinoside, quercetin-3-O- $\alpha$-L-rhamnoside, epigallocatechin 3-O-P-coumarate, quercetin 3-O-(6"-acetyl-galactoside) 7O-rhamnoside, quercetin 3-(4"-acetylrhamnoside) 7rhamnoside and (-)-epi-afzelechin. Table 1 showed the respective area width in the ESI+ mode at $0.66,3.60,2.10$, $4.73,3.32,2.16,5.34,3.20$ and $6.24 \%$, respectively. Meanwhile, Table 2 shows the corresponding values for ESI- at $2.53,13.58,8.56,13.55,7.55,15.42,19.00,11.65$ and $0.70 \%$.

The area width of these nine compounds differed in the ESI+ and ESI- mode, due to the difference in the ion used, as described above. In the positive ion mode, there was an additional proton (hydrogen ion) $\left[\mathrm{M}+\mathrm{H}^{+}\right]$, while in negative ion mode, there was a loss of one proton $\left[\mathrm{M}-\mathrm{H}^{+}\right]$, therefore, the results obtained were different. These results were also in line with the reports by Ramakrishnan et al. (2018) and Zeng et al. (2018), stating the difference in ions used led to difference in the concentration and type of each active compound identified.

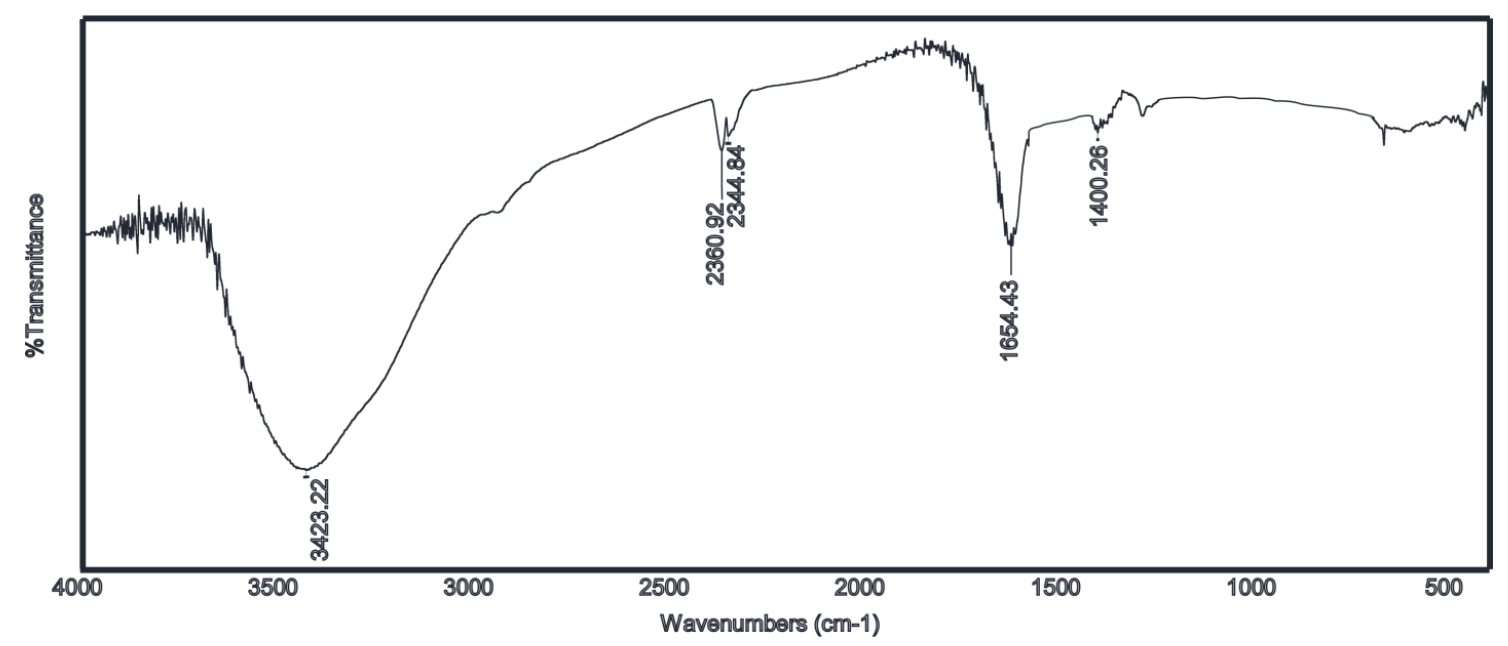

Figure 1. Screening of GLB functional groups using FTIR 


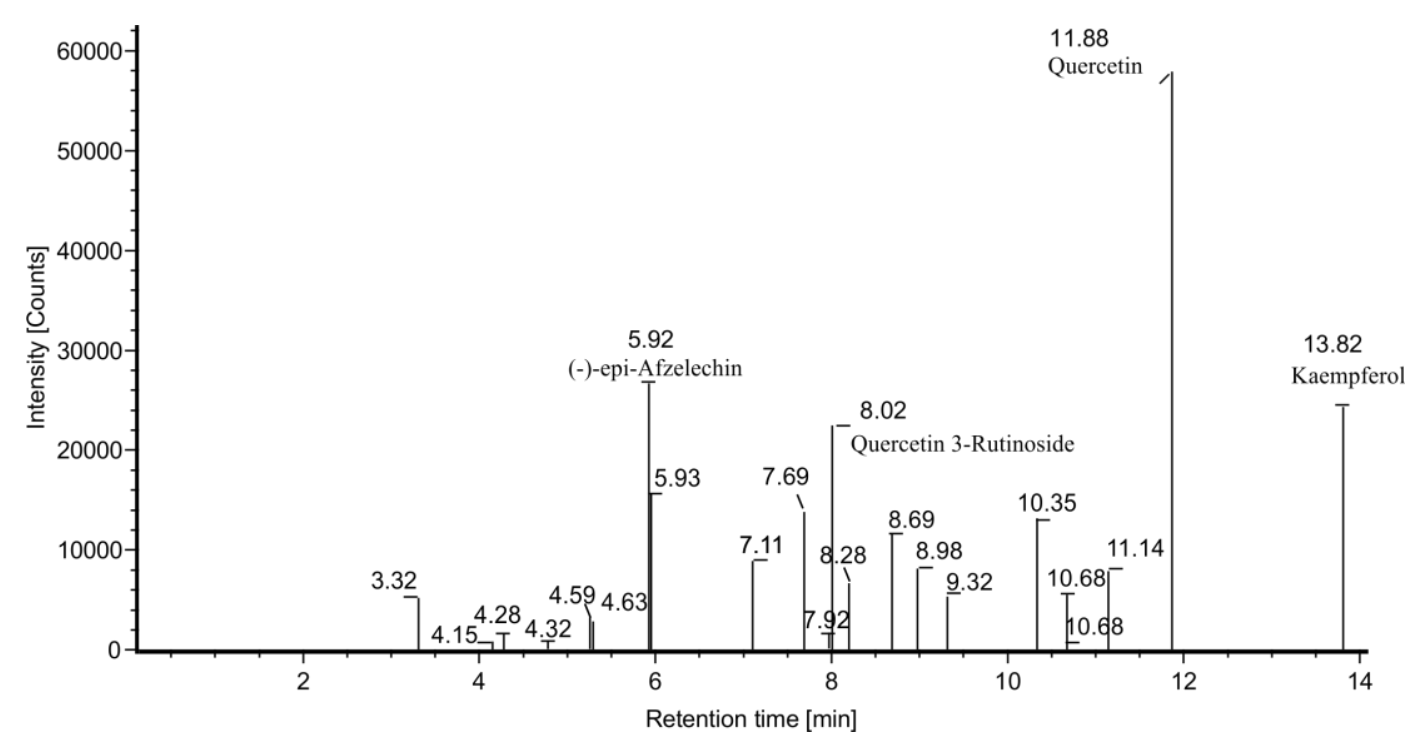

Figure 2. LCMS total ion chromatogram of GLB on positive ionization mode

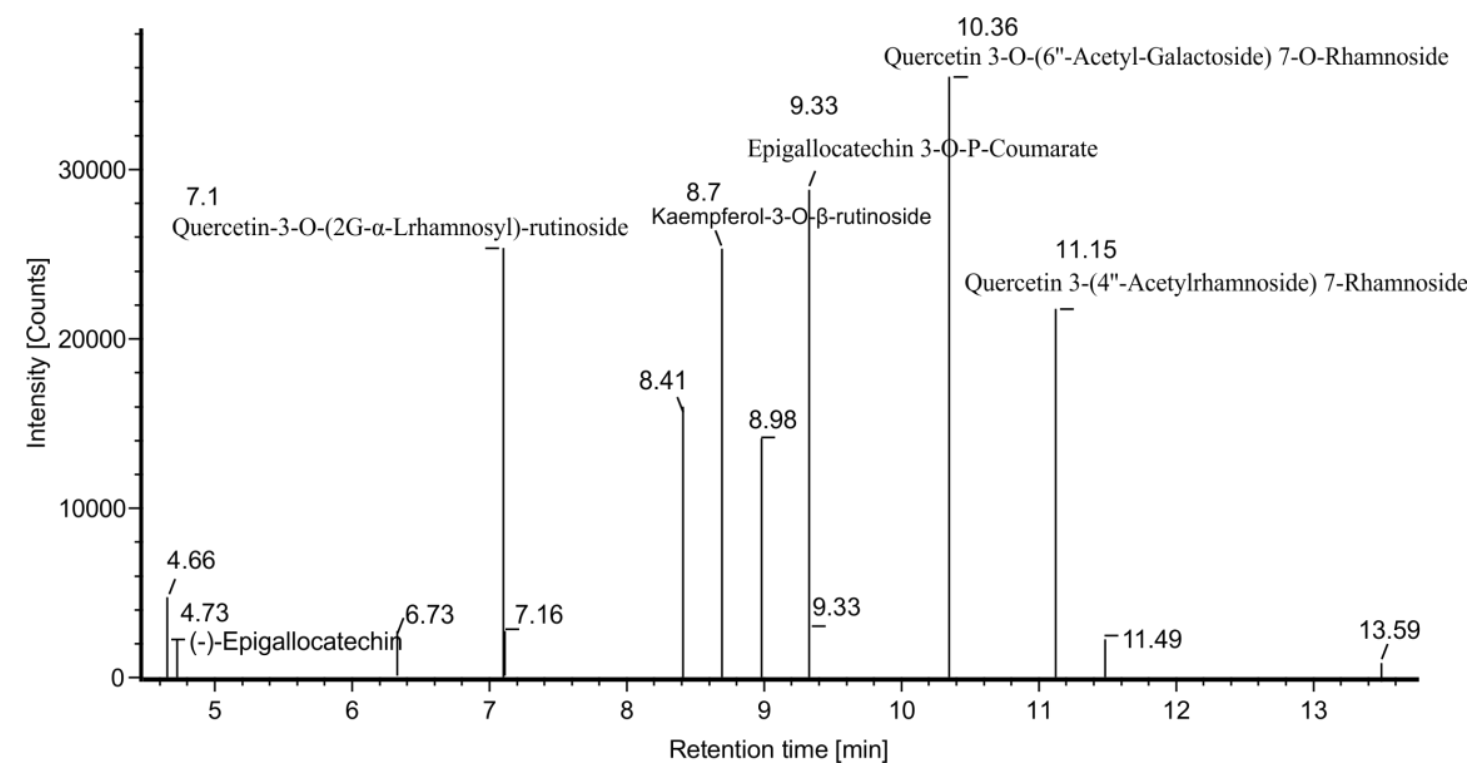

Figure 3. LCMS total ion chromatogram of GLB on negative ionization mode

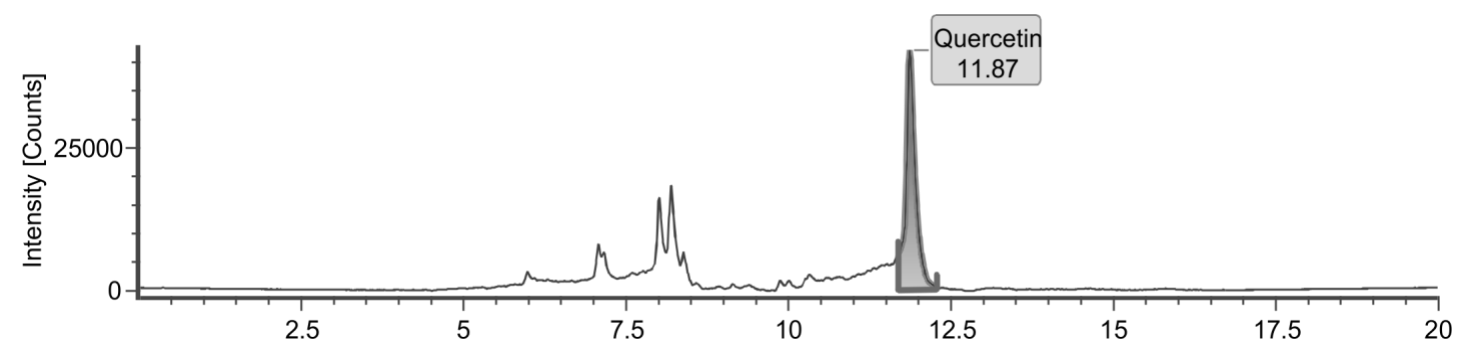

Figure 4. The chromatogram of screening of quercetin compound based on ESI+ mode 


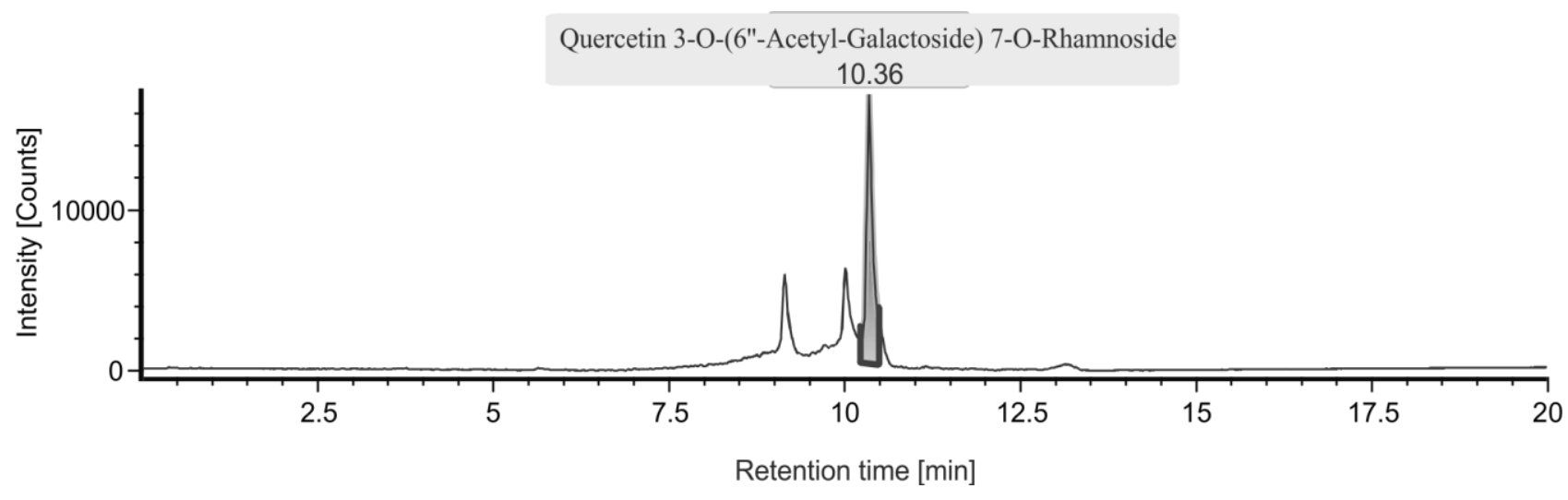

Figure 5. The chromatogram of screening of quercetin 3-O-(6"-acetyl-galactoside) 7-O-rhamnoside by ESI- mode of LC-MS/MS QTOF

In this study, some of active compounds appeared in GLB also present in gambir (gambier product). These are quercetin, (-)-epi-afzelechin, kaempferol, cyanidin 3,5diglucoside, and procyanidin as reported by Sazwi et al. (2013) that these compounds are also present in gambier. On the other hand, these active compounds also appeared in the form of bonds with other compounds, such as quercetin 3-glucoside which consists of quercetin and glucoside. This compound appeared on the positive (ESI+) and negative (ESI-) modes in the GLB. In addition, Quercetin 3-rutinoside also consists of quercetin and rutinoside, which was identified in the ESI+ mode only, at 8.02 minutes retention time. This binding reaction was presumed because GLB was reused in the gambier boiling process.

The GLB also presented two active compounds confirmed to have gone undetected in the gambier. These include first norcimifugin, which was further discovered by LC-MS/MS QTOF screening with ESI+ mode at 5.92 minutes retention time, with an area width of $10.85 \%$. Second, oleoresin A was also detected by ESI+ mode at 8.28 minutes, with area width $2.71 \%$. These active compounds are presumably formed through the repeated boiling process on GLB.

The active compounds were consequently identified as flavonoids and were determined to function as antioxidants due to the hydroxy group $\left(\mathrm{OH}^{+}\right)$present. In addition, the products possess the capacity to donate stabilized free radicals (Cao et al. 1997); hence some have been utilized in medicine. For instance, quercetin is adopted in anti-cancer (Rauf et al. 2018), anti-bacterial (Jaisinghani 2017), antioxidant and anti-inflammatory therapy (Lesjak et al. 2018). Also, previous studies have shown the capacity to reduce total serum cholesterol (Mathew et al. 2012) improves immune system ( $\mathrm{Li}$ et al. 2016), and possibly act as a cardiovascular agent (Patel et al. 2018). Meanwhile, gallocatechin-4beta-OI, also known as the leucodelphinidin component demonstrates some anti-diabetic properties (Sharma et al. 2020) and reduces total serum cholesterol (Mathew et al. 2012), while -(-)epi-afzelechin has an inflammatory activity (Malik et al. 2018), and possibly confers protection against bone loss (Wong et al. 2017). In addition, cyanidin 3,5-diglucoside has anti-diabetic properties (Yamane et al. 2019).

Based on FTIR and LC-MS/MS QTOF analysis results, GLB was estimated to contain 27 active compounds, included in the class of flavonoids, and some occur in the gambier (gambier product). Therefore, GLB is a potential raw material for the native medicine industry, and further research is suggested in line with isolating the active compounds.

\section{ACKNOWLEDGEMENTS}

This research was funded by the PMDSU scheme, with the contract number T/12/UN.16.17/PT.01.03/PP/2019. The authors are grateful to the Ministry of Research, Technology and Higher Education, of the Republic of Indonesia, for the provision of financial support and the Rector of Andalas University, Indonesia for the opportunity to conduct this research.

\section{REFERENCES}

Andasuryani, Purwanto YA, Budiastra IW, Syamsu K. 2014 Determination of catechin content in gambir powder from dried gambir determination of catechin content in gambir powder from dried gambir leaves quickly using FT NIR PLS model. Intl J Adv Sci Eng Inf Technol 4 (5): 1-5. DOI: 10.18517/ijaseit.4.5.423.

Arief S, Nasution FW, Labanni A. 2020. High antibacterial properties of green synthesized gold nanoparticles using Uncaria gambir Roxb. leaf extract and triethanolamine. J Appl Pharm Sci 10 (8): 124-130. DOI: 10.7324/JAPS.2020.10814.

BPS. 2020. Sumatera Barat Province in Figures. BPS-Statistics of Sumatera Barat Province, Padang. [Indonesian]

Cao G, Sofic E, Prior RL. 1997. Antioxidant and prooxidant behavior of flavonoids: Structure-activity relationships. Free Radic Biol Med 22 (5): 749-760. DOI: 10.1016/S0891-5849(96)00351-6.

Jaisinghani RN. 2017. Antibacterial properties of quercetin. Microbiol Res 8 (1): 13-14. DOI: $10.4081 / \mathrm{mr} .2017 .6877$.

Kasim A, Asben A, Mutiar S. 2015. Kajian kualitas gambir dan hubungannya dengan karakteristik kulit tersamak. Majalah Kulit, Karet, dan Plastik 31 (1): 55-64. [Indonesian]

Kasim A, Malrianti Y, Derosya V, Syukri D. 2019. Gc-ms screening of valuable volatile compounds in the waste of Uncaria gambir. Ann Biol 35 (2): 242-245. 
Labanni A, Zulhadjri Z, Handayani D, Ohya Y. 2020. The effect of monoethanolamine as stabilizing agent in Uncaria gambir Roxb. mediated synthesis of silver nanoparticles and its antibacterial activity. J Dispers Sci Tech 41 (10): 1-8. DOI 10.1080/01932691.2019.1626249.

Lesjak M, Beara I, Simin N, Pintać D, Majkić T, Bekvalac K, Orčić D Mimica-Dukić N. 2018. Antioxidant and anti-inflammatory activities of quercetin and its derivatives. J Funct Foods 40: 68-75. DOI: 10.1016/j.jff.2017.10.047.

Li Y, Yao J, Han C, Yang J, Chaudhry MT, Wang S, Liu H, Yin Y. 2016 Quercetin, inflammation and immunity. Nutrients 8 (3): 1-14. DOI 10.3390/nu8030167.

Malik A, Zahid S, Jamil U, Zahid A, Ali Q. 2018. Phytochemical potential of $\beta$-Sitosterol, $\beta$-Amyrin and Epiafzelechin in nickel intoxicated multiple organ damage in rat. Intl J Biol Pharm Allied Sci 7 (12): 2090-2103. DOI: 10.31032/IJBPAS/2018/7.12.4599.

Materska M. 2008. Quercetin and its derivatives: Chemical structure and bioactivity - A review. Pol J Food Nutr Sci 58 (4): 407-413.

Mathew BC, Yoseph BA, Dessale T, Daniel RS, Alemayehu A, Campbell IW, Augusti KT. 2012. Hypolipidaemic effect of leucodelphinidin derivative from Ficus bengalensis Linn on cholesterol-fed rats. Res J Chem Sci 2 (2): 54-60. ISSN 2231-606X.

Musdja MY, Hapsari MA, Agusta A. 2017. Comparison of activity and inhibitory mechanism between (+)-catechin and water extract of gambier (Uncaria gambir Roxb.) against some bacteria. Sci J PPIUKM 4 (2): 55-60. DOI: 10.27512/sjppi-ukm/se/a29012018.

Oliver S, Yee E, Kavallaris M, Vittorio O, Boyer C. 2018. Water-soluble antioxidant dextran-quercetin conjugate with potential anticancer properties. Macromol Biosci 18 (4): 1-11. DOI 10.1002/mabi.201700239.

Packialakshmi N, Naziya S. 2014. Fourier transform infrared spectroscopy analysis of various solvent extracts of Caralluma fimbriyata. Asian Biomed Pharm Sci 4 (36): 20-25. DOI: 10.15272/ajbps.v4i36.573

Patel RV, Mistry BM, Shinde SK, Syed R, Singh V, Shin HS. 2018 Therapeutic potential of quercetin as a cardiovascular agent. Eur J Med Chem 155: 889-904. DOI: 10.1016/j.ejmech.2018.06.053

Pavia DL, Lampman GM, Kriz GS. 2001. Introduction to Spectroscopy: A Guide for Students of Organic Chemistry. Saunders College.

Qiao L, Lewis R, Hooper A, Morphet J, Tan X, Yu K. 2013. Using natural products application solution with UNIFI for the identification of chemical ingredients of green tea extract. https://www.waters.com/content/dam/waters/en/appnotes/2013/720004837/720004837-en.pdf

Rahmawati N, Bakhtiar A, Putra P. 2012. Isolasi katekin dari gambir (Uncaria gambir (Hunter). Roxb) untuk sediaan farmasi dan kosmetik. Jurnal Penelitian Farmasi Indonesia 1 (1): 6-10. [Indonesian]

Rajiv P, Deepa A, Vanathi P, Vidhya D. 2016. Screening for phytochemicals and ftir analysis of Myristica dactyloids fruit extracts. Intl J Pharm Pharm Sci 9 (1): 315-318. DOI: 10.22 159/ijpps.2017v9i1.11053.
Ramakrishnan P, Kalakandan S, Pakkirisamy M. 2018. Studies on positive and negative ionization mode of esi-lc-ms/ ms for screening of phytochemicals on Cassia auriculata (Aavaram Poo). Pharmacogn J 10 (3): 457-462. DOI: 10.5530/pj.2018.3.75.

Rauf A, Imran M, Khan IA, ur-Rehman M, Gilani SA, Mehmood Z, Mubarak MS. 2018. Anticancer potential of quercetin: A comprehensive review. Phytother Res 32 (11): 2109-2130. DOI: $10.1002 /$ ptr.6155

Rege SU, Yang RT. 2001. A novel FTIR method for studying mixed gas adsorption at low concentrations: $\mathrm{H}_{2} \mathrm{O}$ and $\mathrm{CO}_{2}$ on $\mathrm{NaX}$ zeolite and $\gamma$ alumina. Chem Eng Sci 56 (12): 3781-3796. DOI: 10.1016/S0009. 2509(01)00095-1

Sazwi NN, Nalina T, Haji Z, Rahim A. 2013. Antioxidant and cytoprotective activities of Piper betle, Areca catechu, Uncaria gambir and betel quid with and without calcium hydroxide. BMC Compl Altern Med 13 (1): 1-12. DOI: 10.1186/1472-6882-13-351.

Sharma P, Joshi T, Joshi T, Chandra S, Tamta S. 2020. In silico screening of potential antidiabetic phytochemicals from Phyllanthus emblica against therapeutic targets of type 2 diabetes. J Ethnopharmacol 248: 112268. DOI: 10.1016/j.jep.2019.112268.

Shi J, Wang Y, Wei H, Hu J, Gao MT. 2020. Structure analysis of condensed tannin from rice straw and its inhibitory effect on Staphylococcus aureus. Ind Crops Prod 145: 112130. DOI: 10.1016/j.indcrop.2020.112130.

Sofyan S, Failisnur F, Salmariza S. 2015. Pengaruh perlakuan limbah dan jenis mordan kapur, tawas, dan tunjung terhadap mutu pewarnaan kain sutera dan katun menggunakan limbah cair gambir (Uncaria gambir Roxb). J Litbang Ind 5 (2): 79-89. [Indonesian]

Torres de C, Díaz-Maroto MC, Hermosín-Gutiérrez I, Pérez-Coello MS. 2010. Effect of freeze-drying and oven-drying on volatiles and phenolics composition of grape skin. Anal Chim Acta 660 (1-2): 177182. DOI: $10.1016 /$ j.aca.2009.10.005.

Wong KC, Cao S, Dong X, Law MC, Chan TH, Wong MS. 2017. (-)Epiafzelechin protects against ovariectomy-induced bone loss in adult mice and modulate osteoblastic and osteoclastic functions in vitro. Nutrients 9 (5): 1-14. DOI: 10.3390/nu9050530.

Yamane T, Imai M, Handa S, Yamada K, Sakamoto T, Ishida T, Inui H, Yamamoto Y, Nakagaki T, Nakano Y. 2019. Reduction of blood glucose and HbA1c levels by cyanidin 3,5-diglucoside in KKAy mice. J Funct Foods 58: 21-26. DOI: 10.1016/j.jff.2019.04.038.

$\mathrm{Yu}$ J, Chuang SSC. 2016. The structure of adsorbed species on immobilized amines in $\mathrm{CO}_{2}$ capture: An in situ IR study. Energy \& Fuels 30 (9): 7579-7587. DOI: 10.1021/acs.energyfuels.6b01423.

Zeng X, Su W, Zheng Y, Liu H, Li P, Zhang W, Liang Y, Bai Y, Peng W, Yao H. 2018. UFLC-Q-TOF-MS/MS-based screening and identification of flavonoids and derived metabolites in human urine after oral administration of exocarpium citri grandis extract. Molecules 23 (4): 1-15. DOI: 10.3390/molecules23040895.

Zheng K, Guo K, Xu J, Liu W, Chen J, Xu C, Chen L. 2020. Study on the interaction between catechin and cholesterol by the density functional theory. Open Chem 18 (1): 357-368. DOI: 10.1515/chem-2020-0038. 